\title{
Subtalar Arthroereisis for the Correction of the Adult Acquired Flatfoot
}

\author{
Ricardo Monreal* \\ Medica Vial Orthopedic Clinic, Alvaro Obregon No.151, Mexico
}

Submission: July 11, 2020; Published: July 24, 2020

*Corresponding author: Ricardo Monreal, Medica Vial Orthopedic Clinic, Alvaro Obregon No.151, Mexico City, Mexico

\section{Introduction}

Adult acquired flatfoot is defined as a progressive deformity of the foot typically presents with flattening of the medial longitudinal arch leading to insufficiency of the medial ankle and hindfoot structures commonly associated with posterior tibial tendon dysfunction. Due to the complexity of the anatomical structures involved in the adult acquired flatfoot is necessary to classify the different variants or stages of this deformity. Johnson and Strom [1] described 3 stages of posterior tibial tendon dysfunction and Myerson [2] adding an additional stage IV. Stage II has been subclassified in $\mathrm{a}, \mathrm{b}$, and c substages according the forefoot supination, forefoot abduction, and medial column instability [3] (Table 1):

Table 1: The Stages of Adult Acquired Flatfoot Deformity.

\begin{tabular}{|c|c|c|c|}
\hline \multirow{2}{*}{ Stages } & \multirow{2}{*}{ Deformity } & \multicolumn{2}{|r|}{ Radiographs } \\
\hline & & Anteroposterior & Lateral \\
\hline I & Pain and swelling along PTT; no deformity & No findings & May see some preexisting flatfoot \\
\hline IIa & $\begin{array}{c}\text { Mild flatfoot deformity, heel valgus }<5 \text { degrees, inverts } \\
\text { past the midline, able to perform single-heel raise, } \\
\text { minimal forefoot abduction }\end{array}$ & $<25 \%$ talar head uncoverage & $\begin{array}{l}<10 \text { degrees of collapse of the talar-first } \\
\text { metatarsal angle }\end{array}$ \\
\hline IIb & $\begin{array}{c}\text { Moderate flatfoot deformity, heel valgus }<15 \\
\text { degrees, may demonstrate inability to invert } \\
\text { heel past the midline, difficulty with single limb } \\
\text { heel raise }\end{array}$ & $\begin{array}{l}\text { Talar head uncoverage of } \\
\text { between } 25 \% \text { and } 40 \%\end{array}$ & $\begin{array}{l}\text { 10-20 degrees of collapse at the talar-first } \\
\text { metatarsal angle }\end{array}$ \\
\hline IIc & $\begin{array}{c}\text { Severe flatfoot but remains flexible, heel valgus } \\
>15 \text {, inability to invert past midline, inability } \\
\text { to perform a single limb-heel raise, lateral subfibular } \\
\text { impingement, severe abduction } \\
\text { deformity }\end{array}$ & Talar head uncoverage $>40 \%$ & $\begin{array}{l}>20 \text { degrees of collapse at the talar-first } \\
\text { metatarsal angle }\end{array}$ \\
\hline III & $\begin{array}{l}\text { Fixed flatfoot deformity; may be able to reduce } \\
\text { heel valgus but residual forefoot varus uncorrectable }\end{array}$ & $\begin{array}{l}\text { Arthritic changes at the tal- } \\
\quad \text { onavicular and } \\
\text { calcaneo cuboid joints may } \\
\text { be seen; deformity typically as } \\
\text { described for the stage IIc }\end{array}$ & $\begin{array}{l}\text { Arthritic changes noted at triple hindfoot } \\
\text { joints will be variable; deformity typically as } \\
\text { described for the stage IIc }\end{array}$ \\
\hline
\end{tabular}




\section{Orthopedics and Rheumatology Open Access Journal (OROAJ)}

\begin{tabular}{|c|c|c|c|}
\hline IVa & $\begin{array}{c}\text { Flexible ankle valgus with underlying flatfoot } \\
\text { foot deformity }\end{array}$ & $\begin{array}{c}\text { Evaluate ankle film for se- } \\
\text { verity of deformity and note } \\
\text { minimal arthritic change; may } \\
\text { utilize fluoroscopy to evaluate } \\
\text { flexibility of the deformity }\end{array}$ & No significant ankle arthritis noted \\
\hline IVb & $\begin{array}{c}\text { Fixed ankle valgus deformity with flatfoot } \\
\text { deformity }\end{array}$ & $\begin{array}{c}\text { Evaluate ankle for severity of } \\
\text { deformity and arthritis }\end{array}$ & $\begin{array}{c}\text { Evaluate ankle for subluxation, joint } \\
\text { space narrowing, osteophytes }\end{array}$ \\
\hline
\end{tabular}

In early stages conservative treatment [4,5] should be considered and several modalities have been used such as, nonsteroidal anti-inflammatory drugs, cast, orthoses, and ankle braces [6,7].

Surgery is indicated in more advanced stages or when conservative treatment has failed, and pain and deformity is present. Various modalities of surgical techniques can be grouped into four categories $[8,9]$ :

i. Soft tissue procedures including primary repair of the tendon, debridement, tenosynovectomy and soft tissue transfer.

ii. Arthrodesis or osteotomies to correct and stabilize joints.

iii. Osteotomies or limited arthrodesis combined with dynamic tendon transfer.

iv. Arthroereisis: Operation that limits the movement of the subtalar joint without fusion (arthrodesis) in order to improve its position.

Arthroereisis has been used predominantly to treat flatfeet in the pediatric population [10]. Viladot et al. [11] reported their experience treating posterior tibial tendon dysfunction stage II with arthroereisis.

\section{Subtalar Arthroereisis for Adult Acquired Flatfoot}

An excessive range of motion of the subtalar joint resulting in adult acquired flatfoot and subtalar arthroereisis procedure is designed to limit hyperpronation. There are numerous clinical studies [12-14] demonstrating satisfactory results after arthroereisis of the subtalar joint for treatment of flexible flatfoot, initially in the pediatric population and later to treat the adult acquired flatfoot due posterior tibial tendon dysfunction. Different modalities have been developed to perform arthroereisis among which are mentioned subtalar temporary staple, sinus tarsi implant, sinus tarsi polyethylene screw, cup silicone implant, and conical implants [15]. Based on their biomechanical properties, sinus tarsi implants are classified into 3 types: Self-locking wedge, axis-altering implant, and impact-blocking device [16]. The majority of sinus tarsi implants are self-locking wedges.

\section{Indications}

Subtalar arthroereisis is useful for correcting valgus in adult acquired flatfoot stage IIa. Stages IIb and IIc (forefoot abduction and medial column stability respectively) will not be corrected with sinus tarsi implant. Tenosynovectomy is not recommended for stage II disease [16].

\section{Discussion}

Acquired flexible flatfoot in adults is a common condition that requires surgery in more advanced stages or when conservative treatment has failed, and pain and deformity is present. The operative procedure most frequently used to treat adult flatfoot secondary to stage II posterior tibial tendon dysfunction consists of medial displacement calcaneal osteotomy and flexor digitorum longus transfer. This technique has proven to be effective for this condition, although calcaneal osteotomies are not free from complications. Subtalar arthroereisis is a method that provides good results in flat foot correction in children [17]. It is an alternative to calcaneal osteotomy in the treatment of stage II of posterior tibial tendon dysfunction, particularly in stage IIa where valgus hindfoot is the main deformity $[11,18,19]$. In the early stage IIa, pain and swelling are noted over the medial ankle, and the patient performs a single-limb heel raise (Figure 1a). The heel is in valgus position when the Rearfoot Angle (RFA) is $\geq 5^{\circ}$ valgus representing a pronated foot type and some forefoot abduction is evident by the appearance of the too-many-toes sign (Figure 1b). With the patient in the seated position, the hindfoot valgus can be corrected to neutral and the forefoot abduction usually corrects quite easily. There is minimal compensatory forefoot varus. Radiographs show $<25 \%$ talar head uncoverage (AP view) (Figure 2a) and $<10$ degrees of collapse of the talarfirst metatarsal angle (lateral view) (Figure 2b).

Subtalar arthroereisis has a greater potential of hindfoot valgus correction than calcaneal osteotomy providing a 3-dimensional correction of the flatfoot deformity by repositioning the talus in its physiologic position [20] (Figure 3). Compared with medial displacement calcaneal osteotomy [21], subtalar arthroereisis (Figure 4) it is easy, quick to perform, and less invasive procedure with no risk of nonunion or malunion, no risk of damaging medial neurovascular structures, and it requires less immobilization time and shorter recovery time. There are also disadvantages among which we can mention: limits subtalar joint mobility, the sinus tarsi level pain rate is relatively high $(10 \%-40 \%$ of patients) which may require implant removal [22]. Calcaneal osteotomy and subtalar arthroereisis can be performed combined on the same patient to gain more heel valgus correction [19]. 


\section{Orthopedics and Rheumatology Open Access Journal (OROAJ)}

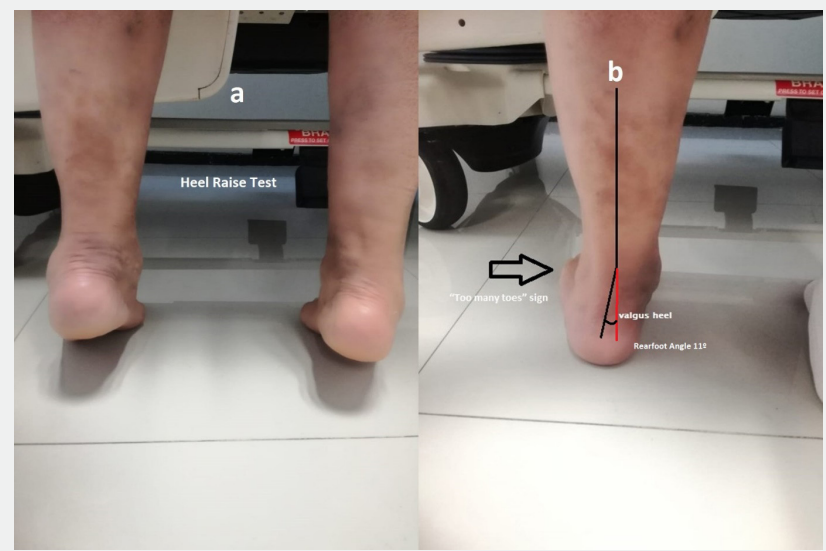

\section{Figure 1:}

a. Single heel rise sign.

b. "Too many toes" sign: When the feet are examined from behind a patient with flatfoot deformity, more toes may be visible laterally (arrow) indicating forefoot abduction. Heel valgus: Rearfoot Angle (RFA) $\geq 5^{\circ}$ valgus represents a pronated foot type, $4^{\circ}$ valgus to $4^{\circ}$ varus a neutral foot and $\geq 5^{\circ}$ varus a supinated foot.

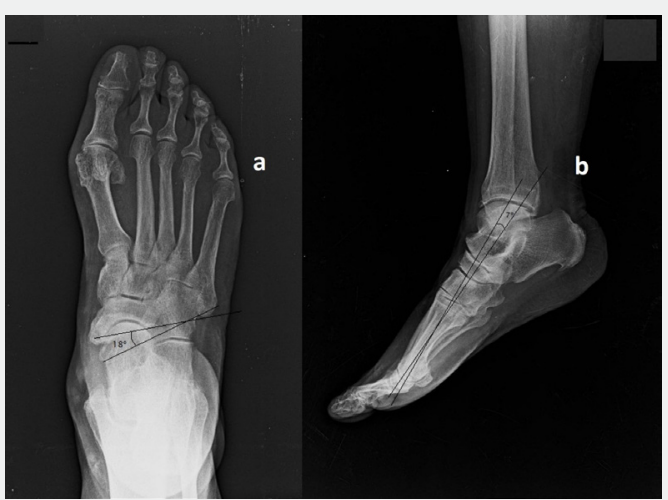

Figure 2:

a. Normal talonavicular coverage angle. The angle between the articular surfaces of the talus and the navicular is less than 7 degrees. Talonavicular uncoverage indicating adult acquired flatfoot stage lla.

b. Normal lateral talar - 1st metatarsal angle (Meary's angle). The long axis of the talus is angled plantar ward in relation to the first metatarsal, consistent with adult acquired flatfoot stage lla

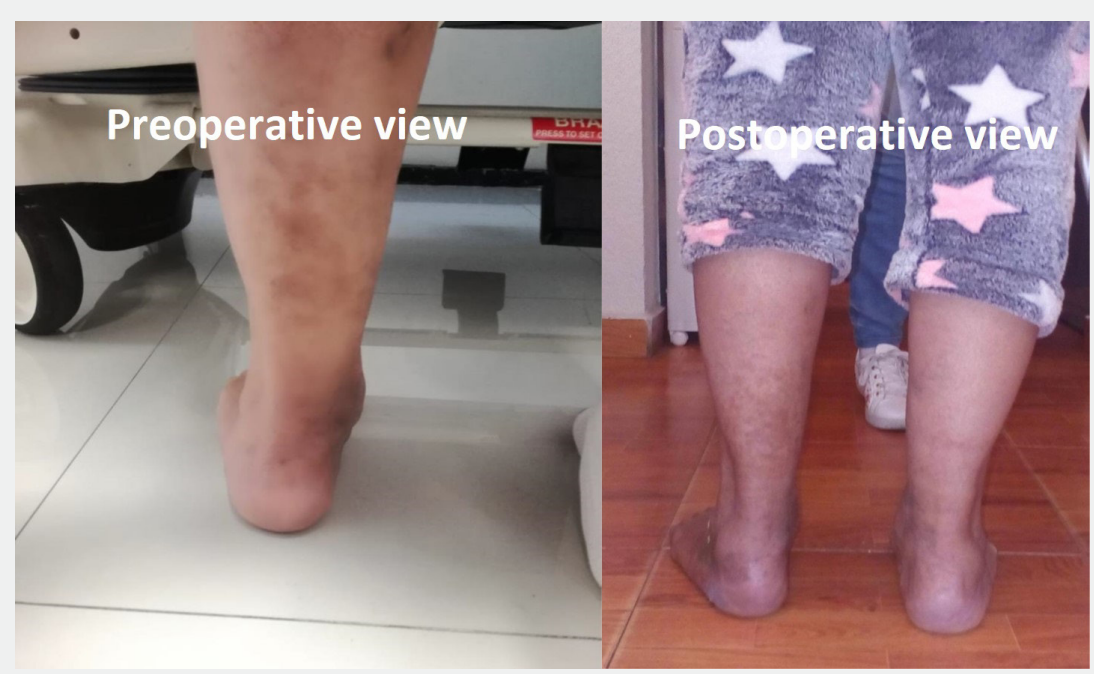

Figure 3: Correction of the deformity is observed after surgery. 


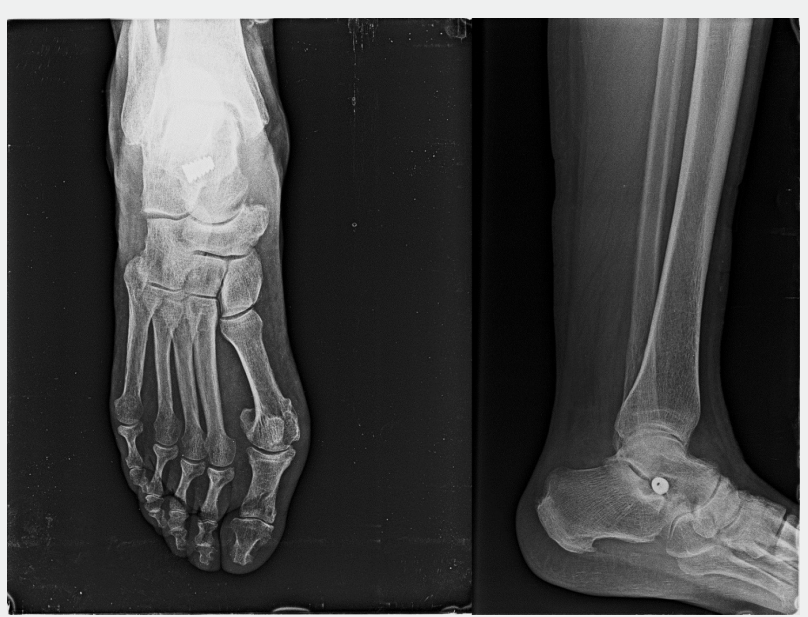

Figure 4: Postoperative anteroposterior and lateral radiographs of a patient with stage lla flatfoot deformity who underwent subtalar arthroereisis.

\section{Conclusion}

Subtalar arthroereisis is an alternative to calcaneal medializing osteotomy to treat adult acquired flatfoot stage IIa. Pain in the sinus tarsi is the most common complication that usually disappears after removal of implant.

\section{Declaration of conflicting Interests}

The author declared no potential conflicts of interest.

\section{References}

1. Johnson KA, Strom DE (1989) Tibialis posterior tendon dysfunction. Clin Orthop 239: 196-206.

2. Myerson MS (1996) Adult acquired flatfoot deformity. J Bone Joint Surg Am 78: 780-792.

3. Bluman E, Title CI, Myerson MS (2007) Posterior tibial tendon rupture: a refined classification system. Foot Ankle Clin North Am 12(2): 233249.

4. Noll KH (2001) The use of orthotic devices in adult acquired flatfoot deformity. Foot Ankle Clin North Am 6(1): 25-36.

5. Nielsen MD, Dodson EE, Shadrick DL, Catanzariti AR, Mendicino RW, et al. (2010) Nonoperative care for the treatment of adult-acquired flatfoot deformity. J Foot Ankle Surg 50(3): 311-314.

6. Augustin JF, Lin SS, Berberian WS, Johnson JE (2003) Nonoperative treatment of adult acquired flat foot with the Arizona brace. Foot Ankle Clin 8(3): 491-502.

7. Imhauser CW, Abidi N, Frankel D, Gavin K, Siegler S (2002) Biomechanical evaluation of the efficiency of external stabilizers in the conservative treatment of acquired flatfoot deformity. Foot Ankle Int 23(8): 727-737.

8. Grice DS (1952) An extra-articular arthrodesis of the subastragalar joint for correction of paralytic flat feet in Children. J Bone Joint Surg Am 34: 927-940.

9. Haraldsson S (1962) Operative treatment of pes planovalgus staticus juvenilis. Acta Orthop Scand 32: 492-498.
10. Lelievre J (1970) Current concepts and correction in the valgus foot. Clin Orthop 70: 43-55.

11. Viladot R, Pons M, Álvarez F, Omana J (2003) Subtalar arthroereisis for posterior tibial tendon dysfunction: a preliminary report. Foot Ankle Int 24: 600-606.

12. Zaret DI, Myerson MS (2003) Arthroereisis of the subtalar joint. Foot Ankle Clin North Am 8(3): 605-617.

13. Needleman RL (2005) Current topic review: subtalar arthroereisis for correction of flexible flatfoot. Foot Ankle Int 26(4): 336-346.

14. Subotnick S (1977) The subtalar joint lateral extra-articular arthroereisis: a follow-up report. J Am Podiatry Assoc 67(3): 157-171

15. Smith SD, Millar EA (1983) Arthroereisis by means of the subtalar polyethylene peg implant for correction of hindfoot pronation in children. Clin Orthop 181: 15-25.

16. Vogler H (1987) Subtalar joint blocking operations for pathological pronation syndromes. In: McGlamery ED, editor. Comprehensive textbook of foot surgery. Baltimore: William \& Wilkins pp. 466-82.

17. Viladot A (1992) Surgical treatment of the child`s flatfoot. Clin Orthop 283: 34-38.

18. Giannini S (1998) Operative treatment of the flatfoot: why and how. Foot Ankle Int 19: 52-58.

19. Pablo Fernández de Retana, Fernando Álvarez, Gustavo Bacca (2012) Is There a Role for Subtalar Arthroereisis in the Management of Adult Acquired Flatfoot? Foot Ankle Clin N Am 17(2): 271-281.

20. Duo Wai-Chi Wong, Yan Wang, Wenxin Niu, Ming Zhang b (2020) Finite element analysis of subtalar joint arthroereisis on adult-acquired flexible flatfoot deformity using customized sinus tarsi implant. Journal of Orthopaedic Translation.

21. Schon LC (2007) Subtalar arthroereisis: a new exploration of an old concept. Foot Ankle Clin North Am 12(2): 329-339.

22. Amol Saxena, Alessio Giai Via, Nicola Maffulli, Haywan Chiu (2016) Subtalar Arthroereisis Implant Removal in Adults: A Prospective Study of 100 Patients. The Journal of Foot \& Ankle Surgery 55(3): 500-503. 

(C) Commons Attribution 4.0 License

DOI: 10.19080/OROAJ.2020.16.555944

\section{Your next submission with Juniper Publishers} will reach you the below assets

- Quality Editorial service

- Swift Peer Review

- Reprints availability

- E-prints Service

- Manuscript Podcast for convenient understanding

- Global attainment for your research

- Manuscript accessibility in different formats ( Pdf, E-pub, Full Text, Audio)

- Unceasing customer service

Track the below URL for one-step submission https://juniperpublishers.com/online-submission.php 